УдК $343.9 ; 343.341$

DOI https://doi.org/10.32837/yuv.v0i2.2145

\author{
Г. Устінова-Бойченко, \\ кандидат юридичних наук, доцент, \\ завідувач кафедри кримінально-правових дисциплін \\ Криворізького факультету \\ Національного університету «Одеська юридична академія»
}

\author{
М. Богатирьова, \\ старший викладач кафедри соціально-політичних та економічних дисциплін \\ Криворізького факультету \\ Національного університету «Одеська юридична академія» \\ T. Черниш, \\ викладач кафедри конституційного, міжнародного та приватного права \\ Криворізького факультету \\ Національного університету «Одеська юридична академія
}

\title{
ГЕНЕЗА ВСТАНОВЛЕННЯ ВІДПОВІДАЛЬНОСТІ ЗА «СТВОРЕННЯ НЕ ПЕРЕДБАЧЕНИХ ЗАКОНОМ ВОЄНІЗОВАНИХ АБО ЗБРОЙНИХ ФОРМУВАНЬ»
}

\begin{abstract}
Конституція України захищає український народ та державний суверенітет й забороняє створення i функціонування будь-яких збройних формувань, не передбачених законом [1]. Воєнізовані формування (такі, що мають організаційну структуру військового типу, а саме: єдиноначальність, підпорядкованість та дисципліну, і в яких проводиться військова або стройова; фізична підготовка [2]) створюють певну загрозу нормальному функціонуванню державних інститутів, побудові громадянського суспільства та соціальному життю окремих громадян. Заборона створювати не передбачені законами України збройні формування (тобто воєнізовані групи, які незаконно мають на озброєнні придатну для використання вогнепальну, вибухову чи іншу зброю [3]) має імперативний характер. Особи, які здійснюють керівництво такими формуваннями, a також займаються їх фінансуванням, постачанням їм зброї, боєприпасів, вибухових речовин чи військової техніки, підлягають кримінальній від-

повідальності за ч. 3 ст. 260 Кримінального Кодексу. Особи, які беруть участь у складі збройних та воєнізованих формувань у нападі на підприємства, установи, організації чи на громадян, несуть відповідальність відповідно до ч. 4 ст. 260 Кримінального Кодексу [4].

Створення не передбачених законом воєнізованих або збройних формувань має формальний склад і вважається закінченим із моменту створення воєнізованого або збройного формування. У більшості випадків незаконне збройне формування утворюється 3 метою ведення бойових дій чи виконання поліцейських функцій на певній території. Керівництво формуванням здійснюється за рахунок управлінських функцій щодо об'єднань, рот або іншої групи або інших іiі учасників із метою забезпечення діяльності цього формування. Під фінансуванням потрібно розуміти надання або збір коштів, або надання фінансових послуг, усвідомлюючи, для якої мети вони надаються. Участю в діяльності не передбачених законом
\end{abstract}


воєнізованих або збройних формувань вважається членство в таких формуваннях, перебування у їх складі та виконання будь-яких дій для їх успішного функціонування [5, с. 324].

Нині в українському суспільстві склалися сприятливі умови щодо виникнення воєнізованих та збройних формувань, що складає відносно самостійний вид злочинності.

Злочинність - це закономірне, необхідне і в цьому змісті звичне явище в житті цивілізованого суспільства [6, с. 452]. Злочинність розвивається паралельно 3 розвитком суспільства, проходить усі етапи його становлення, виникають нові ii форми, а наявні набувають більш складних форм.

Як влучно відзначав М.С. Таганцев, сталість правових норм перевіряється умовами їхнього історичного розвитку. Право створюється народним життям, живе та видозмінюється разом із ним, тому зрозуміло, що сталими можуть бути лише ті положення закону, в яких відбилися народні погляди, що склалися історично, закону, що не має коріння в історичних умовах народного життя, загрожує ефемерність, він може стати мертвою літерою [7, с. 10].

Для розуміння складу кримінального правопорушення, відношення держави та суспільства до цього негативного кримінального явища потрібно в історичному аспекті проаналізувати становлення кримінальної відповідальності за створення не передбачених законом воєнізованих або збройних формувань та визначити, на який момент розвитку Української держави виникла необхідність кримінально-правової заборони на створення не передбачених законом воєнізованих або збройних формувань.

Проводячи дисертаційне дослідження, С.Ф. Денисов пропонує такі етапи розвитку кримінального законодавства України:

- період до заснування Київської держави - до XI ст.;
- період Київської держави -

XI-XV ст.;

- Литовсько-польська доба -

XV-XVI ст.;

- доба козацька - XVI-XVIII ст.;

- занепад козаччини і українського життя - XVIII - до 1917 р.;

- радянський період - 19171991 рр.;

- українське відродження 1991 - сьогодення [8, с. 10].

Необхідність заборони воєнізованих формувань на початку розвитку країни не існувала, оскільки центральна влада могла самостійно забезпечувати зовнішню та внутрішню безпеку. Натомість вона не могла контролювати процеси формування воєнізованих формувань певних територій держави та їі суб'єктів, влада яких спиралася на ці військові формування. Як правило, це були війська окремих князів, згода яких потрібна була для вирішення питання про ведення військових дій проти іншої держави та участі їх військових загонів у таких діях. 3 укріпленням влади суверена у всіх сферах суспільного життя відбуваються процеси централізації, що створило передумови для спротиву 3 боку воєнізованих формувань князівств або інших суб'єктів. Таким чином, виникла потреба в забороні формування незалежних від центральної влади воєнізованих формувань.

Перші нормативні згадування встановлення відповідальності за створення не передбачених законом воєнізованих або збройних формувань знаходять відображення під час козацької доби у XVIII ст. Так, у «Воинском Артикуле», який був прийнятий Петром I у 1715 р., у 19 артикулі передбачалася відповідальність особи за такі дії: «...тот кто войско вооружит или оружие предпримет против его величества» або ж того, хто не повідомив про вчинення зазначеного злочину, 3 установленням покарання у виді четвертування 3 конфіскацією майна [9, с. 327]. 
Суворість покарання за ці діяння пояснюється необхідністю захисту влади, посяганням на яку вважалося найтяжчими діяннями.

Необхідності встановлення відповідальності за вказані вище дії у кримінальному законодавстві передувало виникнення козацьких військ, які були самостійними військовими формуваннями. Це викликало необхідність передбачити відповідну норму в кримінальному законодавстві, оскільки з появою можливості створення подібних формувань ймовірними стають протиправні діяння, а саме збройне повстання проти царя.

Збірник 1743 р. «Права за якими судиться малоросійський народ» містив узагальнену судову практику, царські укази, норми церковного права та правові звичаї. Відповідальність за створення військових формувань «вооружене войско», метою діяльності яких було вчинення повстання проти існуючої влади [10, с. 211].

Із першої половини XIX ст. на території України, яка повністю втратила свою автономію, почали діяти загальноімперські закони, а саме Уложение «О наказаних уголовных и исправительных» від 15 серпня 1845 p. (з наступними редакціями у $1857,1866,1885$ роках). У контексті теми дослідження інтерес становить третій розділ цього нормативного акта «О преступлениях государственных», в якому у шостій главі «О тайных обществах и запрещенных сходбищах» передбачалась відповідальність за створення або участь у «тайных, под каким бы то ни было наименованием, обществ, имеющих вредную для спокойствия или целости государства, или противную установленным законам образу и порядку правления цель», з встановленням покарання у виді вислання у Сибір або ув'язнення у фортецю від 6 місяців до 1 року. На відміну від раніше чинних законів, у зазначеному вже передбачалося розділення відповідальності учасників, залежно від ї ролі у таких «тайных обществах». Покарання за своєю суворістю відповідало суспільній небезпечності цього діяння. У кримінальному законі 1854 р., у розділі VIII «Преступления и проступки против общественного благоустройства и благочиния» у третій главі «Нарушение общественного спокойствия, порядка и ограждающих оные постановления» у ч. 1 ст. 63 була встановлена відповідальність: «За составление злонамеренных шаек и вступление в оныя ... составившие сообщество для преступлений государственных, а равно и вступившие в оные». Крім того, у цьому законі передбачалася відповідальність осіб за постачання таким «шайкам» зброї, приховування майна, здобутого їх учасниками злочинним шляхом та приховування самих учасників [11, с. 108].

За вказані вище діяння передбачалося покарання: вислання у віддаленні губерніі, каторжні роботи до 6 років, віддання в арештантські роти до 8 років, у робочі дома до 1 року. Окрім того, у ч. 5 цієї статті передбачалася відповідальність учасників цих об'єднань за вчинення будь-яких інших злочинів, із призначенням покарання, яке було встановлено за ці злочини відповідно до кримінального законодавства [11, с. 109].

Кримінальне законодавство 1927 року не передбачало норми, в якій прямо встановлювалася б відповідальність за створення або участь у не передбачених законом збройних формуваннях. Проте в Особливій частині 3'явилася норма, яка відображала політику нового уряду країни, спрямовану на боротьбу $з$ існування або діяльності будь-яких указаних вище угруповань. Так, у Кримінального Кодексу 1927 р. в главі I «Контрреволюционные преступления» ст. 542 передбачалась відповідальність за збройне повстання або вторгнення на радянську територію збройних банд, захоплення влади у центрі або на місцях з цією ж метою, зокрема з метою насильницького від- 
торгнення від Союзу РСР і окремої союзної республіки, будь-якої частини iï територіï [12, с. 72]. За вказані вище діяння передбачалося покарання: розстріл або оголошення ворогом трудящих $з$ конфіскацією майна і з позбавленням громадянства Союзу РСР або позбавлення волі на строк не менше трьох років з конфіскацією всього або частини майна [12, с. 72].

Крім того, слід зазначити, що 3 моменту утворення Радянського Союзу відповідно до ст. 49 Конституції РРФСР усі питання стосовно організації воєнізованих або збройних формувань були віднесені до виключної компетенції Всеросійського з”ізду Рад та Всеросійського Центрального Виконавчого Комітету Рад, і організація зазначених формувань проти їх волі визнавалися контрреволюційними злочинами [13].

Таке положення у кримінальному законодавстві збереглося до 1960 р. Верховною Радою УРСР, 28 грудня 1960 р., було прийнято новий Кримінальний Кодекс [14, с. 458].

Уперше відповідальність за створення не передбачених законом воєнізованих формувань або груп була встановлена законодавцем шляхом доповнення KK 1960 року. Так, 11.11 .1993 р., Кримінального Кодексу доповнено кримінально-правовою нормою, яка була розміщена в розділі IX «Злочини проти порядку управління». Із метою кращого розуміння сутності нововведення наведемо витяг зі ст. 1876 Кримінального Кодексу1960 року:

«Ст. $187^{6}$ «Створення не передбачених законодавством воєнізованих формувань або груп»:

Створення не передбачених законодавством воєнізованих формувань або груп або участь у їх діяльності карається позбавленням волі на строк від двох до восьми років 3 конфіскацією майна або без такої.

Керівництво вказаними в частині першій даної статті формуваннями або групами, їх фінансування, поста- чання їм зброї, боєприпасів, вибухових речовин або військової техніки карається позбавленням волі на строк від трьох до десяти років з конфіскацією майна або без такої.

Участь у складі передбачених частиною першою даної статті формувань або груп в нападі на державні, суспільні підприємства, установи, організації або окремих громадян карається позбавленням волі на строк від семи до п'ятнадцяти років 3 конфіскацією майна або без такої» [15, с. 750].

Нормативна конкретизація ознак незаконних воєнізованих формувань або груп за часів становлення незалежності України більше було викликано потребою регулювання нових видів правовідносин у суспільстві. Набуття незалежності та формування демократичного суспільства створило можливості для об'єднання людей, що на період нестабільності та реформування державних інститутів могло стати загрозою для нормального функціонування державної влади та безпеки держави в цілому.

Прийняття Кримінального Кодексу України 2001 року посилило регулювання цієї сфери суспільного життя. Нові положення Кримінального Кодексу України 2001 року відображають безпосередню спрямованість на посилення протидії організованій злочинності кримінально-правовими засобами. 3 огляду на нормативні визначення, що були запозичені з Кримінального Кодексу1960 року, $€$ підстави констатувати наявність у чинному кримінальному законодавстві України сукупності кримінально-правових норм, які визначають специфіку, особливості притягнення до відповідальності та призначення покарання за конкретні форми складної співучасті в організованій злочинній діяльності, а також звільнення від відповідальності учасників злочинних спільнот [4].

Ураховуючи обставини, яка склались за останні сім років у нашій державі, надзвичайно актуальним стало 
питання виявлення й розслідування фактів створення не передбачених законом воєнізованих або збройних формувань. Чітко визначені суб'єктивно-об'єктивні ознаки складу кримінального правопорушення «Створення не передбачених законом воєнізованих або збройних формувань» містяться у статті 260 KK України.

Об'єктивна сторона цього злочину виражається в таких формах: 1) у створенні не передбачених законами України воєнізованих формувань; 2) участі у їхній діяльності; 3) у створенні не передбачених законом збройних формувань; 4) участі у їхній діяльності; 5) в керівництві зазначеними формуваннями, їх фінансуванні, постачанні їм зброї, боєприпасів, вибухових речовин чи військової техніки; участі у складі зазначених формувань у нападі на підприємства, установи, організації чи громадян [4].

3 об’єктивної сторони цього кримінального правопорушення обов'язковою є незаконність створення воєнізованого або збройного формування. Відповідно до Конституції України «на території України забороняється створення i функціонування будьяких збройних формувань, не передбачених законом» (ч. 6 ст. 17 Kонституції України), «політичні партії та громадські організації не можуть мати воєнізованих формувань» (ч. 2 ст. 37 Конституції України). Незаконними є воєнізовані формування, створення яких заборонено Конституцією України, а також воєнізовані та збройні формування, не передбачені законами України [1].

Із суб'єктивного боку така протиправна дія характеризується тільки прямим умислом, тобто учасники цих формувань усвідомлюють його незаконність і свою належність до нього. Суб'єктами такого кримінального правопорушення $є$ осудні особи, які досягли 16-річного віку [5, с. 325].

Дослідивши історико-правовий аналіз створення не передбачених законом воєнізованих або збройних формувань в українському законодавстві, можна сказати, що становлення кримінально-правової норми, що досліджується у чинному кримінальному законодавстві, є історично обумовленим фактом.

На території сучасної України перші згадки щодо встановлення відповідальності за створення не передбачених законом воєнізованих або збройних формувань з'явилися за козацьку добу у XVIII ст. Норми, які визначали заборони створення різного роду воєнізованих формувань, змінювалися залежно від модернізації державних інститутів та впливу суспільства на державну владу Нині чинне кримінальне законодавство відповідає реаліям сьогодення та $€$ результатом багаторічної нормативної діяльності.

У статті досліджено законодавство в історичному аспекті щодо формування ознак кримінального правопорушення «Створення не передбачених законом воєнізованих або збройних формувань». Конституциійні гарантії щзодо захисту держави та населення від не передбачених законом воєнізованих або збройних формувань викликають підвищений інтерес у відношенні зазначеного складу кримінального правопорушення. Необхідність заборони створювати воєнізовані та збройні формування поза межами впливу державної влади виникла з розвитком держави та укріпленням державної влади. Загроза впливу таких формувань на реалізацію державної влади зумовила необхінність контролювати діяльність збройних та воєнізованих формувань, дозволивши їх функціонування тільки під керуванням відповідних державних інститутів, та заборону їх ненормативного створення та існування.

Перші закони, які забороняли створення не передбачених законом воєнізованих або збройних формувань та встановлювали від- 
повідальність за їх створення, були прийняти під час козацької доби. У 1715 роияі Петром I було прийнято «Воинской Артикул» та у 19 артикулі передбачалася відповідальність особи за такі діï.

Під час періоду, коли Україна повністю втратила свою самостійність та автономію, діяли загальноімперські закони, які були спрямовані на абсолютну заборону створення воєнізованих або збройних формувань та встановлення суворої відповідальності за вчинення таких дій.

Кримінальне законодавство 1927 року та 1960 року продовжувало конкретизацію кримінально-правових та кримінологічних характеристик складу злочину «Створення воєнізованих або збройних формувань». Прийняття Кримінального Кодексу України 2001 року посилило регулювання иієї сфери суспільного життя.

Проаналізовані iсторичнi аспекти реагування держави на «Створення не передбачених законом воєнізованих або збройних формувань» вказують на те, що конкретизація характеристики зазначеного складу кримінального правопорушення є результатом багаторічної нормативної діяльHocmi.

Ключові слова: воєнізовані формування, збройні формування, створення не передбачених законом воєнізованих або збройних формувань, кримінальні правопорушення проти громадської безпеки, ознаки кримінального правопорушення.

Ustinova-Boichenko

H., Bohatyrova M., Chernysh T. Genesis of establishment of responsibility for "Creation of military or armed formations not provided by law"

The article examines the legislation in the historical aspect of the formation of signs of a criminal offense Creation of non-statutory paramilitary or armed groups. Constitutional guarantees for the protection of the state and the population from paramilitary or armed groups not provided for by law arouse increased interest in relation to the specified composition of the criminal offense. The need to ban the creation of paramilitary and armed formations outside the influence of state power arose with the development of the state and the strengthening of state power. The threat of the influence of such formations on the exercise of state power necessitated the control of the activities of armed and paramilitary formations, allowing them to operate only under the control of relevant state institutions and prohibiting their non-normative creation and existence.

The first laws prohibiting the creation of non-statutory paramilitary or armed groups and establishing responsibility for their creation were adopted during the Cossack era. In 1715, Peter I adopted the "Military Article" and Article 19 provided for the responsibility of the person for such actions.

During the period when Ukraine completely lost its independence and autonomy, general imperial laws were in force, which were aimed at the absolute prohibition of the creation of paramilitary or armed formations and the establishment of strict responsibility for such actions.

The criminal legislation of 1927 and 1960 continued to specify the criminal law and criminological characteristics of the crime "Creation of paramilitary or armed groups". The adoption of the Criminal Code of Ukraine in 2001 strengthened the regulation of this sphere of public life.

The analyzed historical aspects of the state's response to the "Creation of non-statutory paramilitary or armed groups" indicate that the specification of the characteristics of this criminal offense is the result of many years of regulatory activity. 
Key words: paramilitary formations; armed formations, creation of paramilitary or armed formations not provided by law, criminal offenses against public safety, signs of a criminal offense.

\section{Література}

1. Конституиї̈ України від 28 червня 1996 р. Відомості Верховної Ради України. 1996. № 30. Cm. 141.

2. Арутюнов А.А. Субъект преступления совершенного в соучастии. Современное право. 2002. № 9. С. 29-31.

3. Бардин А. Н. Насилие, как существенный признак терроризма. Право $i$ безпека. 2002. № 2. С. 157-161.

4. Кримінальний кодекс України : Закон України від 05.04.2001 р. № 2341-III (із змінами та доповненнями). Відомості Верховної Ради України. 2001. № 25. Cm. 131 .

5. Сухонос В. В., Білоконь Р. М., Сухонос В. В. (мол.). Кримінальне право України. Особлива частина : підручник. Суми : ПФ «Видавництво «Університетська книга», 2020. 672 с.

6. Бачинин В.A. Философия права и преступления. Харків : Фолио, 1999. $608 \mathrm{cs}$.

7. Навроцький В.О. Склад злочину $i$ його роль у процесі кримінально-правовоі кваліфікації. Правничий часопис Донеи̧ького університету. 2000. № 1. С. 47-51.
8. Денисов С.Ф. Кримінальна відповідальність за злочини проти громадської моралі (cm.cm.210, 211, 2111 КК України) : автореф. дис. ... канд. юрид. наук. Kü̈, 1996. 22 c.

9. Российское законодательство Х-ХХ вв. Т. 4. Москва : Юридическая лumepamypa, 1986. 432 c.

10. Хрестоматія з історіі держави i права України : навчальний посібник. Київ: Юрінком Інтер, 2003. 565 с.

11. Проскуряков О. Руководство к познанию действующих русских государственных, гражданских, уголовныхи полищейских законов. Т. 3. Санкт-Петербург : Королев и комп., 1854 г. 275 c.

12. Уголовный кодекс УССР в редакции 1927 г. / Сост. Курицкий И.И., Гиммельфарб Л.А., Шихмантер Н.И. Харків: Юридическое издательство НКЮ УССР, 1927. 322 c.

13. Мельник М.I., Клименко В.А. Кримінальне право України. Загальна частина: підручник. Київ : Юридична думка, 2004. 352 c.

14.Андрусів Г.В., Андрушко П.П., Лиховая С.Я. Кримінальне право Украіни. Особлива частина : підручник. Київ : Юринком Iнтер, 1999. 896 с.

15. Уголовный кодекс Украины: Научно-практический комментарий / Под ред.: Шакун В.И., Яиенко С.С. 5-е издание. Киев : A.К.C., 1999. 1088 c. 